AJAR

7,1

2

Received 12 November 2020 Revised 7 January 2021 13 February 2021 Accepted 21 February 2021

\section{The influences of Shariah governance mechanisms on Islamic banks performance and Shariah compliance quality}

\author{
Md. Kausar Alam ${ }^{\circledR}$ \\ Department of Business Administration, University of South Asia, \\ Dhaka, Bangladesh \\ Mohammad Mizanur Rahman \\ Department of Business Administration, International Standard University, \\ Dhaka, Bangladesh \\ Mahfuza Kamal Runy \\ Department of Management, Eden Mohila College, Dhaka, Bangladesh \\ Babatunji Samuel Adedeji \\ Department of Accounting and Finance, Universiti Putra Malaysia, \\ Serdang, Malaysia, and \\ Md. Farjin Hassan \\ Department of Finance, Putra Business School, Serdang, Malaysia
}

\begin{abstract}
Purpose - The purpose of this paper is to examine the influences of Shariah governance (SG) mechanisms on Islamic banks' performance and Shariah compliance quality in the context of Bangladesh.

Design/methodology/approach - A semi-structured personal interview tactic was applied to accomplish the research objectives. The data were collected from the regulators, Shariah supervisory boards, Shariah department executives and Shariah experts from the Central Bank (Bangladesh Bank) and Islamic banks in Bangladesh.

Findings - The study discovers that the quality of the Board of Directors (BODs), Shariah Supervisory Board (SSB), management and Shariah executives have both positive and negative influences on the Shariah compliance quality, image, goodwill and performance of Islamic banks' in Bangladesh. The compositions, formations and quality of SSB and Shariah officers positively influence the Islamic banks' fatwas, Shariah decisions, compliance quality and firm performance. The study also finds that prevailing banking pressure, current political situation, the willingness of BOD and management and social limitations impact Islamic banks' performance, Shariah compliance quality, image and goodwill.

Research limitations/implications - Based on our findings, if the regulators, BODs and Islamic banks can manage effective and efficient executives, it will create a positive impact on Islamic banks' performance, image, goodwill and quality compliance. As the prevailing banking pressure, current political situation and social limitations hinder the functions and employment system of the Islamic banks as well as result the Islamic
\end{abstract}

\footnotetext{
(C) Md. Kausar Alam, Mohammad Mizanur Rahman, Mahfuza Kamal Runy, Babatunji Samuel Adedeji and Md. Farjin Hassan. Published in Asian Journal of Accounting Research. Published by Emerald Publishing Limited. This article is published under the Creative Commons Attribution (CC BY 4.0) licence. Anyone may reproduce, distribute, translate and create derivative works of this article (for both commercial and non-commercial purposes), subject to full attribution to the original publication and authors. The full terms of this licence may be seen at $\mathrm{http} / /$ /creativecommons.org/licences/by/4.0/legalcode

The authors would like to thanks the Editor-in-Chief of AJAR and anonymous reviewers for the constructive comments and beneficial suggestions for the improvement of our paper. The authors do not receive any research grant and funds for this project.
}

Asian Journal of Accounting Research

Vol. 7 No. 1, 2022

pp. $2-16$

Emerald Publishing Limited

$2443-4175$

DOI 10.1108/AJAR-11-2020-0112 
banks' image, performance, Shariah implementations and compliance. Thus, the theorist needs to consider these mechanisms in extending the agency, stakeholder and resource dependence theories.

Originality/value - This research extends the literature concerning the influences of Islamic banks' SG mechanisms in Bangladesh. The study also argued not only the efficient and effective mechanisms but also the prevailing banking pressure, current political situation and social limitations impact on Islamic banks' performance and Shariah compliance quality.

Keywords Shariah governance, Shariah governance mechanisms, Islamic banks performance, Shariah compliance quality, Bangladesh

Paper type Research paper
Influences of Shariah governance mechanisms

\section{Introduction}

The world financial crisis has enlarged the attention of the banks' governance and performance (Al-Gamrh et al., 2020; Salina et al., 2020; Aebi et al., 2012). The recent studies have significantly focused on the performance and responsibility of the Boards of Directors (BODs) and their roles in risk-taking and moral values in banking functions. Srairi (2013) outlined that state-owned Islamic banks incline to be more stable and less uncovered to credit risk than conventional banks. Therefore, numerous researchers have pointed that the financial crisis is responsible for the failures of corporate governance (CG). The vast number of financial losses born by the global prominent financial institutions constitutes a conventional CG mechanism's failure. However, during the financial crisis, the performance of Islamic banks was comparatively better than traditional banks because of different reasons such as less visible liquidity risk (Ali, 2020; Kassim and Abdulle, 2012), better credit and assets growth systems, contributing to economic and financial constancy (Hasan and Dridi, 2011), more prudent risk management behavior and higher solvency (Aslam et al., 2020; Aslam and Haron, 2020; Chazi et al., 2018).

However, previous literature also hypothesized that Islamic banks requisite to enhance their institutional image and reputation through Shariah compliance quality, which is the unique feature that differentiates them from their conventional counterparts (Belal et al., 2015). As the philosophies and principles recommended by Islamic belief diverge distinctly from the structures implemented in general CG, there are extensive normative (Islamic doctrines and values) and critical examinations concerning Islamic governance frameworks (Abu-Tapanjeh, 2009; Kamla et al., 2006). For instance, conventional CG underlines financial performance with profit maximization, while Shariah governance (SG) emphasizes Shariah principles purely. Theoretically, Islamic banks are devoted to social well-being, and their business promotions diversified it from conventional banks (Hasan and Dridi, 2011). Therefore, Islamic banks have inaugurated the Shariah Supervisory Board (SSB) to confirm the overall compliance with these principles, as their backers and promoters (Nomran et al., 2018; Mollah and Zaman, 2015; Hamdallah, 2012).

Moreover, Islamic banks have to concentrate on profit maximization. Indeed, a reasonable consensus in the literature has recommended that Islamic banks should increase their profitability. However, prior researchers focused on the Shariah supervision, performance, audit quality and credit rating of Islamic banks (Hamdallah, 2020; Nomran et al., 2018; Almutairi and Quttainah, 2017; Mollah and Zaman, 2015). Earlier literature outlines that proprietorship concentration has a statistically positive impact on Shariah-based corporations' performance (Shahrier et al., 2020). Also, distinct competency concerning BOD members' higher education significantly enhances firms' performance (Shahrier et al., 2020). Practically, BOD members with well knowledge and skills will confirm compliance with Shariah doctrines (Shahrier et al., 2020). Furthermore, the empirical findings concerning CG and corporate performance outline a relationship between governance and corporations' success; for example, weak governance mechanisms have wider agency problems resulting in 
AJAR 7,1 little organizational success (Joslin and Müller, 2016; Ozkan, 2007); and prominent stockholder have a positive influence on corporal achievement (Joslin and Müller, 2016).

However, these studies did not cover the influence of SG mechanisms on both sides of Islamic banks' performance and Shariah compliance quality. In addition, previous researchers examined the SG practices, problems and challenges, legal and regulatory issues of the SG, Shariah compliance and disclosure, application of SG guidelines in the context of Bangladesh (Alam et al., 2020a, b, c, d; Alam et al., 2019; Ullah and Khanam, 2018; Abdullah and Rahman, 2017). Thus, there is an opportunity to investigate the influences of SG mechanisms on Islamic banks' performance and Shariah compliance quality in the context of Bangladesh. To attain this objective, we will examine the question, "how do you think that the appointment criteria, composition, qualification and quality of Board of Directors (BODs), SSB, management, and Shariah department officers influence Islamic banks performance and Shariah compliance quality? If yes, How? If not, why?".

The study is significant as it varies from previous inquiries and contributes to the existing literature in numerous ways. Firstly, this is the first education to explore the influence of SG mechanisms of Islamic banks' performance and Shariah compliance quality in Bangladesh. The literature concerning Islamic banking is normally normative and theoretical, and there are few experimental pieces of evidence on their Shariah compliance. Contrasting with the past research which mainly focused on the conventional banks' performance (i.e. Joslin and Müller, 2016) or providing theoretical implications concerning the Islamic banks' uniqueness as a result of SG (Al-Gamrh et al., 2020; Nomran et al., 2018; Hasan, 2011), the empirical findings of this study focused on the influence of SG mechanisms in the performance and Shariah compliance quality of the Islamic banks in Bangladesh.

Secondly, the research extends the literature of Islamic banking and SG mechanisms, performance and quality compliance in Bangladesh, which is unexplored for several decades. Thirdly, the study significantly extends the literature of SG by outlining the composition and formations of the SSB and Shariah officers, which positively influence fatwas development, Shariah decision-making, institutional performance and Shariah compliance quality. These directly enhance the confidence and beliefs of the general people and customers. The study significantly contributed to the national and global regulatory bodies by providing suggestions that the Islamic banks, regulators and BOD should provide competent, knowledgeable and efficient executives that will positively impact Islamic banks' performance, image and quality compliance. Finally, the study extends the concerns that not only the efficiency and effectiveness of mechanisms but also the prevailing banking pressure, current political situation and social limitations also hinder the functions and employment system of the Islamic banks. As a result, these affect the Islamic banks' image, performance, Shariah implementations and compliance. Thus, the theorist needs to consider these mechanisms in the extension of the agency, stakeholder and resource dependence theories as well as in selecting the resources.

The following part of the paper is structured as follows. Section 2 provides the literature review along with theoretical underpinning. Section 3 outlines the data collection and analysis processes of the study. Section 4 describes the empirical evidence, and finally, Section 5 illustrates the concluding remarks.

\section{Literature review}

\subsection{Shariah governance}

The corporate governance framework is the agenda of guidelines and practices by which BOD confirms responsibility, justice and transparency with the numerous stakeholders (customers, investors, shareholders, management, employees, government and society). The government and regulators promulgate the corporate governance guideline to control the 
institutions as well as to protect the interest of all concerned stakeholders. CG model of Islamic banks is constructed based on the principles of property rights and contracts, the need to shape structure to confirm the Shariah law for safeguarding the stakeholders' rights (Bhatti and Bhatti, 2009). Consequently, SG is a complete system that outlines how Islamic Financial Institutions (IFIs) follow the Shariah principles in conducting their business functions (Ginena and Hamid, 2015). IFSB-9 (2009) illustrated SG systems as "a set of structural procedures where IFIs assure the Shariah compliance through its operational activities". The Accounting and Auditing Organization for Islamic Financial Institutions (AAOIFIs) accounting standards assist as guidelines that might have reflections on the distinct features of IFIs and fulfill the continuous demands of this industry. As AAOIFI guidelines and accounting standards are not mandatory for the IFIs, it may drive to problems of comparability, reliability and compliance level measurement (Sarea and Hanefah, 2013).

Literature has investigated the association between governance mechanisms and firm performance comprising the value of the shareholders in financial and nonfinancial institutions (Al-Gamrh et al., 2020; Aslam and Haron, 2020; Harun et al., 2020; Khalid, 2020; Nomran et al., 2018). However, the experiential studies are diversified. Numerous earlier research studies report a positive outcome of CG on the value of nonfinancial institutions (Gerged and Agwili, 2020). In contrast, Hutchinson (2002) found a negative relationship between $C G$ and firm value. Consequently, some studies have also investigated the association between governance and performance in the banking industry and found a positive, negative and no relationship (Al-Gamrh et al., 2020; Nomran et al., 2018; Adams and Mehran, 2012). The previous study recommended that strong BOD and its size enhances bank performance (Adams and Mehran, 2012).

\subsection{Theoretical framework}

Agency theory illustrates the prearranged connection between the managers and shareholders, similar to an agent and principal relation complete the functions in support of the principal (Jensen and Meckling, 1976). Agency theory claims that management roles are not only protecting the interest of shareholders and that shareholders monitor management behavior to minimize the management's opportunistic actions (Jensen and Meckling, 1976). However, the oversight function of the BOD is one of the monitoring roles of the shareholders. The BOD signifies "a market-induced institution, the ultimate internal monitor of the set of contracts called a firm" (Fama, 1980). BOD has accountability to protect the shareholders' interest and benefit through the supervisor of accounting and financial reports and to enhance firm performance. In addition, the stakeholder theory suggests a broader concept of CG and SG be executed in the corporations. The stakeholder theory outlines better freedom in broadening the idea of $\mathrm{CG}$ as management takes care of the interest of shareholders and other stakeholders through its activities (Freeman, 1994; Collier, 2008). Therefore, management has provided responsibilities to formulate numerous corporate guidelines for maintaining business legitimacy, foremost to improve corporate stakeholders' trust (Ashforth and Gibbs, 1990; Suchman, 1995; Alam et al., 2020c; Tabash et al., 2020).

Studies evidentially showed that the supervisory role and the construction of SSB have positive influences on Islamic banks' performance (Nomran et al., 2018; Mollah and Zaman, 2015). Besides, the SSB size, composition, qualifications, education and knowledge concerning Islamic jurisprudence, contemporary and Islamic finance have positive relationships in IFIs' performance (Almutairi and Quttainah, 2017). Understanding of Shariah, as well as knowledge of finance and accounting, have assisted the SSBs in being allowed for decision making. Again, the vastly qualified SSB members contribute to higher profit, achievements (Nomran et al., 2017). Khan et al. (2017) also state that SSB members' having accounting or finance or economics degrees about Shariah knowledge is positively connected with Islamic banks' performance and profitability. Islamic banks that are involved

Influences of Shariah governance mechanisms 
AJAR 7,1

with reputed SSB members, can firmly provide the SG guidelines and principles, and share information disclosure, and reveal additional corporate social responsibility information in annual reports. Such kind of SSB can also accomplish other active roles in monitoring and guiding the overall banking functions and advise the management to enhance the SG quality, increase the operational services, performance and disclosure of the bank (Ajili and Bouri, 2018). Thus, regarding the limitations of the current study, CG results in lower firm performance, initiates agency conflicts (Ozkan, 2007), emphasizes sound and complete CG. This statement supports the formation of IFIs, a comprehensive and sound SG, which is obligatory and reflects assurances' steady progress in the industry.

Resource dependence theory illustrates how the external resources of the corporations affect their ruling. The gaining of external resources is a significant belief in every corporation's tactical and strategic management. Existing literature also indicates that this theory emphasizes on corporation necessities to be used as the resources from the alternative player in the setting, and which describes the insufficiency of resources can strengthen corporations to obey new structures that employ alternate resources (Pfeffer and Salancik, 1978; Sherer and Lee, 2002). Therefore, several researchers have used this theory in empirical studies (Sharif and Yeoh, 2014; Hillman et al., 2000). These studies indicate and discuss the significance of this theory in illustrating the actions of the corporations, in the appointment of BOD and executives, the structure of the agreement, business policies and linkage with the external corporate relations. The studies investigate associations, joint ventures, and unions and achievements to overwhelm dependencies and advance corporal independence and legitimacy.

However, the resource dependence standpoint also allows a wider acknowledgment of how resource dependencies reveal particular governance mechanisms within sound governance structures and functions of the BOD and management. The advocatory viewpoint of resource dependence deliberates BOD as a key institutional body that supports effective resources for the firm, minimize transaction costs in conducting the exterior connections and protect corporations from ecological uncertainties (Huse, 2005; Lynall et al., 2003). Besides, the BOD will reduce the individual board member's limitations concerning corporate proficiency over a set of policymaking structures that sequentially enhances better corporate strategic resolutions and accomplishments (Ruigrok et al., 2006). Based on this perspective, it can be commonly estimated that the effectiveness of a SG system would recommend the proper components of Shariah compliance quality in its operations. In addition, outdoor directors also perform a significant role in assisting the specific resources, which may be absent in the management (for instance, monetary funds, information); retrieving external and powerful corporations (for example, regulatory authorities, consulting firms and international standard-setting institutions); legitimacy and experienced knowledge and leadership (Tabash et al., 2020; Alam et al., 2020e; Lynall et al., 2003; Hillman et al., 2000).

All of these studies indicate and discuss the significance of these theories concerning the actions of the corporations, the appointment of BOD and executives, the structure of the agreement, business policies and linkage with the external corporate relations (Karbhariet al., 2020). The studies investigate associations, joint ventures, and unions as well as achievements, in determining overwhelming dependencies and advance corporal independence and legitimacy. Also, outdoor directors perform a significant role in assisting the specific resources, which may be absent in the management (for instance, monetary funds, information); retrieving external and powerful corporations (for example, regulatory authorities, consulting firms, and international standard-setting institutions); legitimacy and experienced knowledge and leadership (Hillman et al., 2000; Pfeffer and Salancik, 1978). However, it can be estimated that the effectiveness of an SG system would produce proper components of Shariah compliance quality in its operations. 


\section{Methodology}

This study is based on qualitative research to understand how and why things occur (Cooper and Schindler, 2011). It comprises "an array of interpretive techniques which seek to describe, decode, translate, and otherwise come to terms with the meaning, not the frequency, of certain more or less naturally occurring phenomena in the social world" (Cooper and Schindler, 2011, p. 162). This study has implemented qualitative research rather than quantitative research as the researchers intend to discover the answer for "how" questions rather than "how many" questions (Silverman, 2010, p. 11). Besides, the researchers consider this study as an exploratory investigation that comprises "an attempt to determine whether or not a phenomenon exists" (Dane, 1990, p. 5). The case study technique (Yin, 2003) provides an understanding of the complete roles and responsibilities of the BOD and its connections with the employed management. As a qualitative technique, the case study strategy offers a profound understanding of CG practices in a particular perception and assists the study's critical objective. Therefore, the study is based on case study research to find out the influences of SG mechanisms in the performance and Shariah compliance quality of the Islamic banks. The case study's essential features focus on "how" and "why" questions (Myers, 2009) and hence it is fit for descriptive and exploratory understandings (Mouton, 2001). Another reason for choosing a case study is that the researchers cannot deploy real behavioral actions (Yin, 2003). Here, the interview question is related to the regulators, SSB members, field experts and Shariah department executives of the Islamic banks.

This study followed the same research methodology applied by the prior researchers in the context of Bangladesh in accomplishing overall research objectives (Alam et al., 2020a, b, 2021). Their studies discovered the reasons for the absence of a comprehensive SGF for Islamic banks in Bangladesh (Alam et al., 2020a), the formation of a central Shariah supervisory authority (Alam et al., 2020b), influence of BOD and management in applying SG guidelines (Alam et al., 2020c), problems of SGF and related bodies of the Islamic banks in Bangladesh (Alam et al., 2020d), external Shariah audit and Shariah compliance of Islamic banks (Alam et al., 2020e); and expected roles and performed duties and functions of SSBs of Islamic banks in Bangladesh (Alam et al., 2021). They found that the intentions of the regulators and concerned stakeholders are responsible for the absence of a comprehensive SGF of Islamic banks in Bangladesh (Alam et al., 2020a). Besides, they recommended that if the government and regulators really want, they can form a central regulatory authority for the Islamic banks in Bangladesh.

The semi-structured interview is selected by the researchers to provide additional data about this study as it is more suitable to understand the practical feature of the subject issues comprehensively. This interview tactic permits the investigators to discover more opinions from the respondents, which may cover a wide range of particulars while gathering the answers (Dane, 1990). Besides, this method delivers the chance to the respondents to provide their thoughts about their knowledge and practical understandings (Saunders et al., 2007). In addition, the face-to-face interview may comfort the procedure of getting a clear understanding of the research issues. When a conversation is face-to-face, it helps to find out the in-depth responses from the participants. This process assists the participants in understanding the questions more clearly (Sekaran and Bougie, 2010). Face-to-face interview safeguards the personalities of the participants in providing their opinions, highly valued in the overall data collection procedure (Gillham, 2000). In total, 17 respondents were interviewed to accomplish the research objective as it was saturated (Alam, 2020). The selected respondents for the interviews are regulators, SSB members, Shariah department executives and finally, the field experts from the Islamic banks and the central bank of Bangladesh whose functions are associated with SG functions of Islamic banks (Alam, 2020; Alam et al., 2021). To maintain the confidentiality of the respondents, the study has used symbolic identifications for the respondents where regulatory respondents are coded as "RA"
Influences of Shariah governance mechanisms 
AJAR 7,1

\section{8}

(Regulatory Aspects), "SP" (Shariah Practitioners) for SSB members, and Shariah department executives and "E" (Experts). The NVivo is used for analyzing massive textual data in qualitative research, as it permits in-depth analysis and delivers more advanced tools to envisage data (Gibbs, 2002). NVivo software is applied to generate codes, categories, and themes (Alam, 2020; Joffe and Yardley, 2004) as it allows the researchers in green data management and analysis rather than the paper and pencil technique (Alam, 2020).

\section{Discussions and findings}

The researchers have collected from Bangladesh, and the respondents were related to the Islamic banking industry and regulatory bodies. The NVivo data analysis identifies three major categories such as effect on performance, Shariah compliance quality and positive impact of SG mechanisms. The study finds that resource mechanisms of every Islamic bank influence on Shariah compliance quality and overall performance. While the SSB and Shariah executives influence on Shariah compliance quality, Islamic banks' business and performance, the management and BOD influence the Islamic banks' performance and implementations of Shariah guidelines and principles. Figure 1 shows the identified theme along with categories from the NVivo data analysis.

The SG mechanisms have influences on Islamic banks' performance and Shariah compliance quality. Most of the participants from all clusters (E\#4, 5; RA\#2; SP\#2, 3, 4, 7) agree in one point that people who are more qualified would confirm the success of Shariah principles and ensure Shariah compliance quality. Practically, it is evident in the context of Bangladesh that the qualified SSBs and BODs influence positively in the performance of Islamic banks and Shariah implementations. These viewpoints positively support the viewpoints of resource dependence theory. Participants from the Shariah side opines that due to the current banking structure, political pressure and social bindings, Islamic banks cannot recruit skilled Shariah candidates as required and the proper function of BOD, which results in banking performance, image and Shariah applications and compliance. Therefore, this limitation creates the opportunity of information asymmetry and pursues management interest, which contradicts the notion of agency theory and stakeholder theory as it impacts business and performance, which is related to wider stakeholders. Banks can also provide training to the general executives as it is quite low and unable to fulfill the demand, and management has limitations in performing these functions since the BOD has selected them.

Figure 1.

Theme of influences of Shariah governance mechanisms on Islamic banks performance and Shariah compliance quality

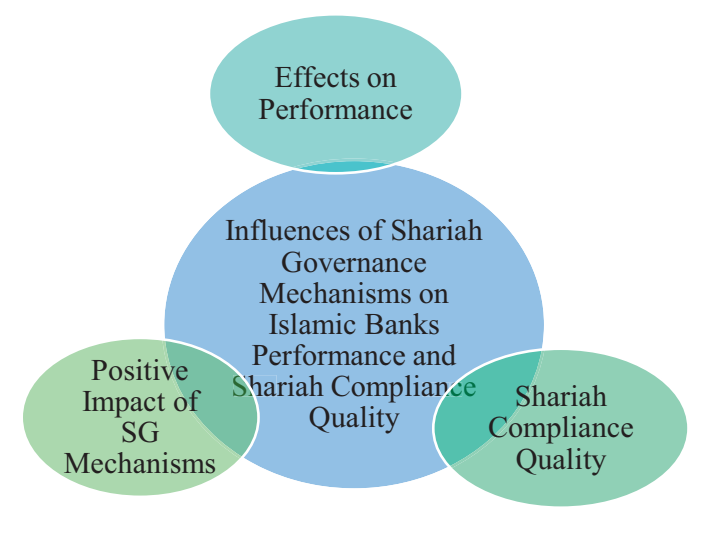

Source(s): Developed by the Authors 
As a result, this lacking and low skills impact on Shariah compliance, business performance and image where have the rights of concerned stakeholders. It is also the responsibility of BOD to recruit qualified, experienced and knowledgeable people for better performance and quality Shariah compliance. So, the respondents raised the question that "it is the matters of questions, on how many Islamic banks have competent SSB? It is a matter of survey."

We saw previously those who are from the Shariah background when they enter the banking, they are competent in both areas, but now we are not getting such combination because of the candidate comes from various courses such as social, political and so on. As a result, the activities of Islamic banking are hampered, and Shariah part being the main part of the Islamic banks is neglected. ........ If even they come from a general background, they should provide proper training and arrange the Islamic banking diploma course. I do not say it is not happening at all, but the ratio is not sufficient. Another issue is that everything is not under management. Few things are also under the BOD. When the BOD recruits the SSB members, there is a lack of competency among these people due to the different reasons such as low qualified members are recruited and prioritized rather than the highly qualified people. [SP\#7]

Additionally, similar views of the participants from the category of experts and Shariah practitioners (E\#3, 4, 5; SP\#2, 9) show that a bank's performance and success largely depend on BOD roles, functions, quality, experiences and knowledge. Conversely, if BODs are not qualified and well experienced, it will negatively impact banks' financial performance. Here, we find a significant similar relationship of the resource dependence theory (Shahrier et al., 2020; Huse, 2005; Lynall et al., 2003).

"BOD can influence their financial performance." [E\#4] "If they are not qualified, not experienced; here will influence the performance". [E\#3] "Yes, of course, their quality and experience are very important." [SP\#2]

However, the empirical evidence shows that individual competency in terms of higher education of board members considerably increases companies' performance (Shahrier et al., 2020). Practically, BOD members with better knowledge and abilities ensure more compliance with Islamic principles (Shahrier et al., 2020). In essence, the institutional procedure of SG sets $\mathrm{SSB}$ as the mainstream of the structure, and this construction has become an essential part of the SGF of IFIs (Hasan, 2011).

Practically, corporations with larger sized boards show positive performance because of the capability of the corporation to budget effectively, access outer capital and tap influence from society (Pfeffer and Salancik, 2003).

In this case, one of the respondents from the Shariah practitioners opined that

"If the members do not have sufficient qualification or experience about the fiqh al muamalat or the banking transactions, then his decisions sometimes will not be consistent with the present situation even for the smooth operation of the bank. It will influence the relations of the public". [SP\#2] "The education qualification, Shariah knowledge and contemporary banking concepts of SSB members influence the decision-making process." [SP\#4]

As a result, one of the regulators having more than 20 years' experience opined that the composition of SSB and Shariah Secretariat in Bangladesh is a mixture of Shariah scholars, bankers, lawyers, professors in Islamic studies and Shariah knowledgeable people for more performance and Shariah compliance quality.

We see that unlike the other banks in the world, only the Fiqh quality based "Kamil" or "Dawra" degree holders are the members of SSB, but in the context of the country, we see that there is a mixture of personalities and knowledge because we want to rip the best benefit. That's why, in our country, we see that there are members from the background of Shariah, studies, education, economics and banking. So, you will get a good mixture of our country's SSB. [RA\#2]

Influences of Shariah governance mechanisms 
AJAR

7,1

However, some Islamic banks do not form their SSB the existing criteria of the central bank, though the guideline has its limitations. This violation generates the opportunity of Shariah's noncompliance functions, income, image and goodwill which contradict with the roles of SSB as an agent of shareholders and all stakeholders. As a result, Islamic banks deprive their stakeholders which are clearly the opposite of stakeholder theory. If the Islamic banks follow the directive in the formation and recruiting of SSB members, the quality of Shariah compliance will undoubtedly increase and improve, which will result in banks' performance, image and goodwill. In this case, Sarker (2005) optimizes that if the quality of Shariah compliance increases, Islamic banking growth will be higher in Bangladesh. Moreover, with the limitations, SSB needs sincerity in their works. It will impact the implementations of Shariah principles and SG guidelines as they are the representatives of the agent and stakeholders.

"At least based on the current requirements of the guideline, if we select SSB members, then the Shariah compliance quality will improve and create goodwill among the people." [SP\#4] "Due to the limitations, we cannot do more, but when we are sincere in our works, it will impact customers' perceptions regarding the Shariah applications. So, if the perfect Shariah scholars can be recruited, then it will help in the banks' business performance and goodwill." [SP\#4]

In terms of global aspects, some countries have already developed standard criteria for SSB members and the Shariah secretariat recruitment system. Besides, Islami Bank Bangladesh Limited (IBBL) has already included the general and Shariah part in their recruitment system, i.e. written examination and viva, which help them to ensure the quality Shariah compliance and operational functions which support the ideas of resource dependence theory. Responses from the Shariah practitioners are given below.

Yes, sure. I know in some banks in Singapore, they imposed conditions, the officer who is willing to join in an Islamic bank must be knowledgeable both in Arabic and Shariah law. Otherwise, an Islamic banker cannot operate Islamic banking properly. If they're more qualified in Arabic and Shariah principles, it will help in the implementation of Shariah compliance. The IBBL recruitment test consists of two parts, i.e. one is general, and another is the Islamic part. These might help them to ensure more Shariah compliance in their operating activities. [SP\#5]

Also, the external members in BOD from the other countries and institutions brought diverse knowledge and experience from their countries and global perspective, which influence the bank's performance and as proven in terms of IBBL's performance. This relationship supports the resource dependence theory. The below responses from the regulators show the relevance of this justification.

"Yes, they bring a lot of experiences from their own countries." "... they have the external members within the BOD like Islamic Development Bank, or Kuwait Finance House, there are members from Qatar, Kuwait. Because of these foreign elements in BOD, you know BOD transparent and professional; there is higher efficiency in the 'Islamic Bank Bangladesh Limited' than many other Islamic banks". [RA\#1]

Conversely, one of the respondents from the Shariah practitioners' side argues that it is partially true, rather than adequately because some bank has well performed and ensured more Shariah compliance only for the commitment and intention of BOD and management. These show a positive relationship between the roles of agents and principles.

"In my view, it is quite true, not fully." [SP\#6] “...... In their system, they train up, provide knowledge and have an organized system of Islamic banking and directed from the top management that we will consider everything but we will not consider or accept the Shariah violation". [SP\#6]

Another respondent from the expert category points out that Shariah compliance and financial performance are different things. Additionally, if the developed products and 
services and the promotion of the product are good, it will influence the Islamic banks' performance. The SSB checks Shariah compliance quality and product promotion instead of product selling.

There are two things; one is financial performance and Shariah compliance. Financial performance is not related to the Shariah experts. It's related to the financial officers. If their product quality, product promotion, and their service quality are good, then these will enhance firm performance. ....... So, Shariah experts can influence Shariah compliance and BOD can influence their financial performance. So, both are different. [E\#4]

Based on the above discussions, SG mechanisms have a positive and negative influence on the Islamic bank's performance and ensuring Shariah compliance quality in the context of Bangladesh.

\section{Conclusion and recommendations}

The study has outlined that the SG mechanisms have influences on Islamic banks' performance and Shariah quality compliance (Al-Gamrh et al., 2020; Ali, 2020; Nomran et al., 2017). The study delineates how SG mechanisms influence Shariah compliance quality and the performance of Islamic banks. This research highlights qualified and experienced SSB, Shariah executives, general executives, management, BOD and people ensure the execution of successful Shariah principles, compliance and performance (Nomran et al., 2018; Almutairi and Quttainah, 2017; Mollah and Zaman, 2015). Therefore, we draw the concept that not only the proper SG mechanisms but also the willingness of the BOD, management and the appropriate system to play a significant role in ensuring Shariah compliance. Secondly, the composition, formations, reputation and quality of SSB and Shariah officers positively influence Islamic banks' fatwas, Shariah decisions, Shariah compliance quality and firm performance that increase trust, confidence and faith of the customer and general people. Thirdly, in terms of Bangladesh, it is already proven that the knowledgeable and qualified BOD and SSB promote their role in ensuring Shariah applications, compliance and firm performance. Thus, one of the reasons for the success of Islamic banks (Shahrier et al., 2020; Hamdallah, 2020; Nomran et al., 2018; Sharif and Yeoh, 2014).

As proven by other studies, this research also has beneficial implications. First, our review is not only useful for Islamic banks but also for the regulators operating in diverse jurisdictions. The results of this study can be a valuable source of knowledge for regulators and policymakers, mostly for the Islamic banking and finance areas, in formulating policies to manage qualified and proper SG mechanisms for appropriate Shariah applications, better performance and quality Shariah compliance. Second, we argued that if BOD can accomplish adequate mechanisms with a combination of qualified, experienced and renowned personalities, definitely it will influence on the Islamic banks' performance positively, as well as Shariah decisions, implementations, Shariah compliance quality, institutional image, transparency, competence and goodwill (Alam et al., 2020c; Nomran et al., 2018; Almutairi and Quttainah, 2017; Mollah and Zaman, 2015). Third, our research has some practical implications for the Islamic banking industries as it is proven that proper mechanisms of resources have significant positive impacts on performance, Shariah compliance quality, image and goodwill.

Fourth, the regulators and BOD should concern about the banking pressures, current political situation and social limitations in developing the SG guidelines so that Islamic banks can perform better in their operational functions as well as ensuring Shariah compliance, which is required and mostly expected by the stakeholders. Thus, the theorist needs to consider prevailing banking pressure, current political situation, social limitations, the willingness of BOD and management as these have an impact on Islamic banks' performance Shariah compliance quality, image and goodwill in the extension of the agency, stakeholder
Influences of Shariah governance mechanisms 
AJAR

7,1

and resource dependence theories as well as in selecting the resources. In conclusion, the research contributes to the literature by highlighting the usage of resources that are consumed to be applied and measured organizational performance in the financial achievement and in conforming Shariah compliance quality in the context of Bangladesh. Contrasting with the past research which mainly focused on the conventional banks' performance (i.e. Aslam et al., 2020; Aslam and Haron, 2020; Chazi et al., 2018), the empirical findings of this study focused on the influence of SG mechanisms in the performance and Shariah compliance quality of the Islamic banks in Bangladesh.

The study is limited to SSB and Shariah officials of Islamic banks and executives of the central of Bangladesh. However, we cannot generalize our findings to be relevant and similar in other Islamic banking practicing countries. This is one of the weakest parts of our study. Therefore, researchers can investigate the influence of resource mechanisms in Islamic banks' performance and Shariah compliance quality in other dual banking practicing countries such as Malaysia, Pakistan and Indonesia as well as the Gulf countries such as Saudi Arabia, Iran, Bahrain and Qatar for further justifications. However, the finding may differ in other jurisdictions and Islamic finance practicing countries. New research can also explore these influences in other Islamic institutions such as services, real-estate companies, Islamic microfinance and cooperative institutions. Researchers can also focus on the willingness of the BOD, management and the appropriate system along with the proper SG mechanisms as these have a crucial role in ensuring Shariah principles and compliance.

\section{ORCID iDs}

Md. Kausar Alam Dhttp://orcid.org/0000-0002-9748-5862

\section{References}

Abdullah, M.F. and Rahman, A. (2017), "Shari'ah governance of Islamic banks in Bangladesh issues and challenges", Journal of Islamic Economics, Banking and Finance, Vol. 13 No. 3, pp. 82-94.

Abu-Tapanjeh, A.M. (2009), "Corporate governance from the Islamic perspective: a comparative analysis with OECD principles", Critical Perspectives on Accounting, Vol. 20 No. 5, pp. 556-567.

Adams, R.B. and Mehran, H. (2012), "Bank board structure and performance: evidence for large bank holding companies", Journal of Financial Intermediation, Vol. 21 No. 2, pp. 243-267.

Aebi, V., Sabato, G. and Schmid, M. (2012), "Risk management, corporate governance, and bank performance in the financial crisis", Journal of Banking and Finance, Vol. 36 No. 12, pp. 3213-3226.

Ajili, H. and Bouri, A. (2018), "Assessing the moderating effect of Shariah Board on the relationship between financial performance and accounting disclosure", Managerial Finance, Vol. 44 No. 5, pp. 570-589.

Al-Gamrh, B., Ismail, K.N.I.K., Ahsan, T. and Alquhaif, A. (2020), "Investment opportunities, corporate governance quality, and firm performance in the UAE", Journal of Accounting in Emerging Economies, Vol. 10 No. 2, pp. 261-276.

Alam, M.K. (2020), "A systematic qualitative case study: questions, data collection, NVivo analysis and saturation", Qualitative Research in Organizations and Management, Vol. 16 No. 1, pp. 1-31, doi: 10.1108/QROM-09-2019-1825.

Alam, M.K., Rahman, S.A., Mustafa, H., Shah, S.M. and Hossain, M.S. (2019), "Shariah governance framework of Islamic banks in Bangladesh: practices, problems and recommendations", Asian Economic and Financial Review, Vol. 9 No. 1, pp. 118-132.

Alam, M.K., Rahman, S.A., Thakur, O.A., Bashir, M.A. and Hosen, S. (2020a), The Reasons behind the Absence of a Comprehensive Shariah Governance Framework for the Islamic Banks in Bangladesh, Vol. 8, No. 1, pp. 134-145. 
Alam, M.K., Tabash, M.I., Thakur, O.A., Sahabuddin, M., Hosen, S. and Hassan, M.F. (2020b), "A central Shariah regulatory authority for the Islamic banks in Bangladesh: legalization or formation”, Journal of Asian Finance, Economics and Business, Vol. 7 No. 1, pp. 91-100.

Alam, M.K., Miah, M.S., Siddiquii, N. and Hossain, M.I. (2020c), "The influences of board of directors and management in Shariah governance guidelines of the Islamic banks in Bangladesh", Journal of Islamic Accounting and Business Research, Vol. 11 No. 9, pp. 1633-1647, doi: 10.1108/ JIABR-08-2019-0155.

Alam, M.K., Mustafa, H., Uddin, M.S., Islam, M.J., Mohua, M.J. and Hassan, M.F. (2020d), "Problems of Shariah governance framework and its mechanisms: an empirical investigation of Islamic banks in Bangladesh", Journal of Asian Finance, Economics and Business, Vol. 7 No. 3, pp. 265-276.

Alam, M.K., Ahmad, A.U.F. and Muneeza, A. (2020e), "External Shariah audit and review committee vis-a-vis Shariah compliance quality and accountability: a case of Islamic banks in Bangladesh”, Journal of Public Affairs. Early View, pp. 1-10, doi: 10.1002/pa.2364.

Alam, M.K., Rahman, S.A., Tabash, M.I., Thakur, O.A. and Hosen, S. (2021), "Shariah supervisory boards of Islamic banks in Bangladesh: expected duties and performed roles and functions", Journal of Islamic Accounting and Business Research. doi: 10.1108/JIABR-02-2020-0035.

Ali, A.M. (2020), "The impact of economic blockade on the performance of Qatari Islamic and conventional banks: a period-and-group-wise comparison”, ISRA International Journal of Islamic Finance, Vol. 12 No. 3, pp. 419-441, doi: 10.1108/IJIF-04-2020-0083.

Almutairi, A.R. and Quttainah, M.A. (2017), "Corporate governance: evidence from Islamic banks", Social Responsibility Journal, Vol. 13 No. 3, pp. 601-624.

Ashforth, B.E. and Gibbs, B.W. (1990), "The double-edge of organizational legitimation", Organization Science, Vol. 1 No. 2, pp. 177-194.

Aslam, E. and Haron, R. (2020), "Does corporate governance affect the performance of Islamic banks? New insight into Islamic countries", Corporate Governance, Vol. 20 No. 6, pp. 1073-1090, doi: 10. 1108/CG-11-2019-0350.

Aslam, E., Haron, R. and Ahmad, S. (2020), "A comparative analysis of the performance of Islamic and conventional banks: does corporate governance matter?", International Journal of Business Excellence, Vol. 22 No. 3, pp. 553-568.

Belal, A.R., Abdelsalam, O. and Nizamee, S.S. (2015), "Ethical reporting in Islami Bank Bangladesh limited (1983-2010)", Journal of Business Ethics, Vol. 129 No. 4, pp. 769-784.

Bhatti, M. and Bhatti, I. (2009), "Development in legal issues of corporate governance in Islamic finance", Journal of Economic and Administrative Sciences, Vol. 25 No. 1, pp. 67-91.

Chazi, A., Khallaf, A. and Zantout, Z. (2018), "Corporate governance and bank performance: Islamic versus non-Islamic banks in GCC countries", The Journal of Developing Areas, Vol. 52 No. 2, pp. 109-126.

Collier, P.M. (2008), "Stakeholder accountability: a field study of the implementation of a governance improvement plan", Accounting, Auditing and Accountability Journal, Vol. 21 No. 7, pp. 933-954.

Cooper, R.D. and Schindler, S.P. (2011), Business Research Methods, 11th ed., McGraw-Hill/Irwin, Singapore.

Dane, F.C. (1990), Research Methods, Brooks/Cole Publishing, Pitman, Belmont, California.

Fama, E.F. (1980), "Agency problems and the theory of the firm”, Journal of Political Economy, Vol. 88 No. 2, pp. 288-307.

Freeman, R.E. (1994), Strategic Management: A Stakeholder Approach, Boston, Massachusetts.

Gerged, A.M. and Agwili, A. (2020), "How corporate governance affect firm value and profitability? Evidence from Saudi financial and non-financial listed firms", International Journal of Business Governance and Ethics, Vol. 14 No. 2, pp. 144-165.

Influences of Shariah governance mechanisms 
AJAR

7,1

Gibbs, G. (2002), Qualitative Data Analysis: Explorations with NVivo, Open University, Kents Hill.

Gillham, B. (2000), Developing a Questionnaire, Continuum, London.

Ginena, K. and Hamid, A. (2015), Foundations of Shari'ah Governance of Islamic Banks, John Wiley and Sons, New York, NY.

Hamdallah, M.E. (2012), “Corporate governance and credibility gap: empirical evidence from Jordan”, International Business Research, Vol. 5 No. 11, pp. 178-186.

Hamdallah, M. (2020), "The reliance of external auditors on the work performed by internal auditors and its impact on audit on banks: a case of the first Abu Dhabi Bank, UAE”, Икономика и управление, Vol. 17 No. 1, pp. 68-80.

Harun, M.S., Hussainey, K., Kharuddin, K.A.M. and Al Farooque, O. (2020), "CSR disclosure, corporate governance and firm value: a study on GCC Islamic banks", International Journal of Accounting and Information Management, Vol. 28 No. 4, p. 607.

Hasan, Z. (2011), "A survey on Shari'ah governance practices in Malaysia, GCC countries and the UK: critical appraisal", International Journal of Islamic and Middle Eastern Finance and Management, Vol. 4 No. 1, pp. 30-51.

Hasan, M.M. and Dridi, J. (2011), "The effects of the global crisis on Islamic and conventional banks: a comparative study", Journal of International Commerce, Economics and Policy, Vol. 2 No. 2, pp. 163-200.

Hillman, A.J., Cannella, A.A. and Paetzold, R.L. (2000), "The resource dependence role of corporate directors: strategic adaptation of board composition in response to environmental change", Journal of Management Studies, Vol. 37 No. 2, pp. 235-256.

Huse, M. (2005), "Accountability and creating accountability: a framework for exploring behavioural perspectives of corporate governance", British Journal of Management, Vol. 16 No. 4, pp. S65-S79.

Hutchinson, M. (2002), "An analysis of the association between firms' investment opportunities, board composition and firm performance", Asia-Pacific Journal of Accounting and Economics, Vol. 9 No. 1, pp. 17-38.

IFSB (2009), Guiding Principles on Shariah Governance Systems for Institutions Offering Islamic Financial Services, Islamic Financial Services Board, Kuala Lumpur.

Jensen, M.C. and Meckling, W.H. (1976), "Theory of the firm: managerial behavior, agency costs and ownership structure", Journal of Financial Economics, Vol. 3 No. 4, pp. 305-360.

Joffe, H. and Yardley, L. (2004), Content and Thematic Analysis Research Methods for Clinical and Health Psychology, Sage, California, pp. 56-68.

Joslin, R. and Müller, R. (2016), "The relationship between project governance and project success", International Journal of Project Management, Vol. 34 No. 4, pp. 613-626.

Kamla, R., Gallhofer, S. and Haslam, J. (2006), "Islam, nature and accounting: Islamic principles and the notion of accounting for the environment”, Accounting Forum, Vol. 30 No. 3, pp. 245-265.

Karbhari, Y., Alam, M.K. and Rahman, M.M. (2020), "Relevance of the application of institutional theory in Shariah governance of Islamic banks", PSU Research Review. doi: 10.1108/PRR-052020-0015.

Kassim, S.H. and Abdulle, M.Y. (2012), "Impact of global financial crisis on the performance of Islamic and conventional banks: empirical evidence from Malaysia", Journal of Islamic Economics, Banking and Finance, Vol. 8 No. 1, pp. 1-12.

Khalid, A.A. (2020), "Role of audit and governance committee for internal Shariah audit effectiveness in Islamic banks", Asian Journal of Accounting Research, Vol. 5 No. 1, pp. 81-89, doi: 10.1108/ AJAR-10-2019-0075.

Khan, I., Khan, M. and Tahir, M. (2017), "Performance comparison of Islamic and conventional banks: empirical evidence from Pakistan", International Journal of Islamic and Middle Eastern Finance and Management, Vol. 10 No. 3, pp. 419-433. 
Lynall, M.D., Golden, B.R. and Hillman, A.J. (2003), "Board composition from adolescence to maturity: a multi theoretic view", Academy of Management Review, Vol. 28 No. 3, pp. 416-431.

Mollah, S. and Zaman, M. (2015), "Shari'ah supervision, corporate governance and performance: conventional vs. Islamic banks", Journal of Banking and Finance, Vol. 58, pp. 419-430.

Mouton, J. (2001), How to Succeed in Your Master's and Doctoral Studies: A South African Guide and Re-Source Book, Van Schaick Publishers, Pretoria.

Myers, M.D. (2009), Qualitative Research in Business and Management, Sage, Los Angeles and London.

Nomran, N.M., Haron, R. and Hassan, R. (2017), "Bank Performance and Shari'ah supervisory board attributes of Islamic banks: does bank size matter?”, Journal of Islamic Finance, Vol. 176 No. 5872, pp. 1-14.

Nomran, N.M., Haron, R. and Hassan, R. (2018), "Shari'ah supervisory board characteristics effects on Islamic banks' performance”, International Journal of Bank Marketing, Vol. 36 No. 2, pp. 290-304, doi: 10.1108/IJBM-12-2016-0197.

Ozkan, N. (2007), "Do corporate governance mechanisms influence CEO compensation? An empirical investigation of UK companies", Journal of Multinational Financial Management, Vol. 17 No. 5, pp. 349-364.

Pfeffer, J. and Salancik, G.R. (1978), The External Control of Organizations: A Resource Dependence Approach, Harper and Row Publishers, New York.

Pfeffer, J. and Salancik, G.R. (2003), The External Control of Organizations: A Resource Dependence Perspective, Stanford University Press, Harper and Row, New York, NY.

Ruigrok, W., Peck, S., Tacheva, S., Greve, P. and Hu, Y. (2006), "The determinants and effects of board nomination committees", Journal of Management and Governance, Vol. 10 No. 2, pp. 119-148, doi: 10.1007/s10997-006-0001-3.

Salina, A.P., Zhang, X. and Hassan, O.A. (2020), "An assessment of the financial soundness of the Kazakh banks", Asian Journal of Accounting Research. doi: 10.1108/AJAR-03-2019-0022.

Sarea, A.M. and Hanefah, M.M. (2013), "The need of accounting standards for Islamic financial institutions: evidence from AAOIFI", Journal of Islamic Accounting and Business Research, Vol. 4 No. 1, pp. 64-76.

Sarker, A.A. (2005), "Islamic banking in Bangladesh: achievements and challenges", Journal of Islamic Economics, Banking and Finance, Vol. 1 No. 1, pp. 45-59.

Saunders, M., Lewis, P. and Thornhill, A. (2007), Research Methods for Business Students, Prentice Hall, Hemel Hempstead.

Sekaran, U. and Bougie, R. (2010), Research Methods for Business: A Skill Building Approach, John Willey and Sons, New York.

Shahrier, N.A., Ho, J.S.Y. and Gaur, S.S. (2020), "Ownership concentration, board characteristics and firm performance among Shariah-compliant companies", Journal of Management and Governance, Vol. 22 No. 3, pp. 1-24.

Sharif, S.P. and Yeoh, K.K. (2014), "Independent directors' resource provision capability in publiclylisted companies in Malaysia”, Corporate Ownership and Control, Vol. 11 No. 3, pp. 113-121.

Sherer, P.D. and Lee, K. (2002), "Institutional change in large law firms: a resource dependency and institutional perspective", Academy of Management Journal, Vol. 45 No. 1, pp. 102-119.

Silverman, D. (Ed.) (2010), Qualitative Research, 3rd ed., Sage, London.

Srairi, S. (2013), "Ownership structure and risk-taking behaviour in conventional and Islamic banks: evidence for MENA countries”, Borsa Istanbul Review, Vol. 13 No. 4, pp. 115-127.

Suchman, M.C. (1995), "Managing legitimacy: strategic and institutional approaches", Academy of Management Review, Vol. 20 No. 3, pp. 571-611.

Influences of Shariah governance mechanisms 
AJAR

7,1

16
Tabash, M.I., Alam, M.K. and Rahman, M.M. (2020), "Ethical legitimacy of Islamic banks and Shariah governance: evidence from Bangladesh”, Journal of Public Affairs. doi: 10.1002/pa.2487.

Ullah, M.H. and Khanam, R. (2018), "Whether Shari'ah compliance efficiency a matter for the financial performance: the case of Islami Bank Bangladesh limited", Journal of Islamic Accounting and Business Research, Vol. 9 No. 2, pp. 183-200.

Yin, R.K. (2003), Case Study Research: Design and Methods, Sage Publishing, Thousand Oaks, California.

\section{Further reading}

Andres, P.D. and Vallelado, E. (2008), "Corporate governance in banking: the role of the board of directors", Journal of Banking and Finance, Vol. 32 No. 12, pp. 2570-2580.

Hirschey, M., John, K. and Makhija, A.K. (2009), Corporate Governance and Firm Performance, Emerald Group Publishing.

\section{Corresponding author}

Md. Kausar Alam can be contacted at: kausarflorence@gmail.com

For instructions on how to order reprints of this article, please visit our website: 